Nowoczesne Systemy Zarządzania Zeszyt 12 (2017), nr 1 (styczeń-marzec) ISSN 1896-9380, s. 15-24

Modern Management Systems

Volume 12 (2017), No. 1 (January-March) ISSN 1896-9380, pp. 15-24
Instytut Organizacji i Zarządzania

Wydział Cybernetyki

Wojskowa Akademia Techniczna

w Warszawie

Institute of Organization and Management

Faculty of Cybernetics

Military University of Technology

\title{
Podnoszenie kwalifikacji przez pracowników wykonujących zadania samorządów gminnych, jako determinanta funkcjonującego modelu zarządzania kadrami - na przykładzie gmin Warmii i Mazur \\ Increase of professional qualifications by employees performing local goverment's tasks as a determinant of the human resources management system based on Warmia and Mazury local goverment's example
}

\author{
Andrzej J. Kozłowski \\ Wyższa Szkoła Policji w Szczytnie \\ Wydział Administracji, Instytut Nauk Społecznych \\ kozlowskiandrzej54@gmail.com \\ Iwona Z. Czaplicka Kozłowska \\ Uniwersytet Warmińsko-Mazurski w Olsztynie \\ Wydział Nauk Ekonomicznych, Katedra Organizacji i Zarządzania \\ iwona.kozlowska@uwm.edu.pl
}

\begin{abstract}
Abstrakt: Funkcjonujący od ponad 25 lat w Polsce samorząd gminny, wraz z rozszerzaniem kompetencji w realizacji zadań mających podstawowe znaczenie dla obywateli, coraz częściej staje się obszarem konkurowania między sobą przedsiębiorstw wykonujących zadania gmin. Sukces w rozwoju konkurujących coraz częściej z sobą gmin jest funkcją rozwoju organizacji i w ich obrębie dysponowaniem wysoko wykwalifikowaną kadrą. Właśnie kwalifikacje i ich stałe doskonalenie uczyniono podstawowym problemem w tym opracowaniu. Za cel postawiono sobie diagnozę podnoszenia kwalifikacji wśród pracowników organizacji wykonujących zadania samorządów gminnych. W prezentowanym artykule, obok przeglądu literatury naukowej, w części badawczej przywołano wyniki badań ankietowych przeprowadzonych na przełomie 2014 i 2015 roku wśród pracowników samorządowych szczebla podstawowego Warmii i Mazur. Przyjęto przed podjęciem badań, że następuje stały wzrost kwalifikacji pracowników samorządowych, ale wzrost ten zróżnicowany jest w odniesieniu do różnych grup zatrudnienia.

Słowa kluczowe: samorząd gminny, przedsiębiorstwo komunalne, kwalifikacje pracowników
\end{abstract}




\begin{abstract}
The communal self-government, functioning in Poland for more than 25 years, simultaneously with broadening competences in the scope of fulfilling tasks of a principal significance for citizens, is more and more frequently becoming the area in which enterprises fulfilling tasks for communes compete with one another. Success in the development of communes, more and more frequently competing with one another, is the result of organizational development, and, within their structures, having highly-qualified staff at disposal. It is those very qualifications and raising them constantly that have been selected as the principal issue to look into in this elaboration. As the objective, formulating the diagnosis of raising qualifications amongst the employees of organizations fulfilling tasks for communal self-governments. In this paper, apart from the review of the scientific literature, in the research part the results of surveys conducted at the turn of 2014 and 2015 amongst self-governmental employees at the basic level in Warmia and Masuria were referred to. Prior to undertaking the research, it had been assumed that there occurred a constant improvement in the qualifications of self-governmental employees, but also that the improvement in question differed in various groups of employees.
\end{abstract}

Keywords: communal self-government, municipal enterprise, qualifications of employees

\title{
Wstęp
}

Wyzwania współczesności wiążą się z wdrażaniem nowoczesnych metod zarządzania we wszystkich sferach życia społecznego i ekonomicznego w wymiarze publicznym i prywatnym. Sprostanie wymogom współczesności wiąże się z wykorzystaniem technologii opierającej się o najnowsze zdobycze nauki. Pracownicy organizacji nastawionych na rozwój i sukces, szczególnie menadżerowie w tych organizacjach, muszą stale śledzić zmiany zachodzące w ich otoczeniu i nabywać nowe umiejętności w wykorzystaniu zasobów organizacji. Z jednej strony rosnąca konkurencja w realizacji potrzeb obywateli, a z drugiej coraz większe oczekiwania jakościowe i ilościowe sprawiają, że produkty muszą osiągać coraz wyższy poziom użyteczności. Ważność sektora publicznego w rozwiązywaniu spraw obywateli sprawia, że kwestią mającą szczególne znaczenie dla sprawnego funkcjonowania organizacji wykonujących zadania tego sektora są kwalifikacje zatrudnionych w nim osób. Sprawność ta wiąże się nie tylko z dysponowaniem wiedzą wyniesioną ze szkół różnych szczebli, ale przede wszystkim ze stałym pozyskiwaniem aktualnej wiedzy i doskonaleniem umiejętności w zarządzaniu i wykorzystaniu zasobów dobra wspólnego. Podnoszenie kwalifikacji, zatem wszelkiego rodzaju szkolenia wewnątrz i na zewnątrz organizacji, to nie tylko rozwój organizacji, ale też klucz do sukcesu pracowników. Kwestię podnoszenia kwalifikacji pracowników przedsiębiorstw wykonujących zadania samorządów gminnych uczyniono podstawowym problemem w tym opracowaniu. W związku ze wzrostem kompetencji tego sektora i częstymi zmianami w prawie, szczególnie samorządów terytorialnych i w ich obrębie samorządów na najniższym szczeblu w strukturze zarządzania państwem, znaczenie ma stworzenie systemu zapewniającego ciągłe doskonalenie kwalifikacji tych pracowników. Prowadząc badania w sektorze publicznym na najniższym szczeblu w strukturze zarządzania państwem, zatem w samorządach gminnych, za cel postawiono sobie dokonanie diagnozy szkoleń i podnoszenia kwalifikacji wśród pracowników organizacji wykonujących zadania samorządów gminnych. W prezentowanym artykule, 
obok przeglądu literatury naukowej, w części badawczej przywołano wyniki badań ankietowych przeprowadzonych na przełomie 2014 i 2015 roku wśród pracowników samorządowych szczebla podstawowego Warmii i Mazur. Przyjęto przed podjęciem badań, że następuje stały wzrost kwalifikacji pracowników samorządowych, ale wzrost ten zróżnicowany jest w odniesieniu do różnych grup zatrudnienia.

\section{Kwalifikacje pracowników samorządowych jako determinanta sprawnego wykorzystania zasobów gmin}

Można przyjąć, że pokolenie Polaków, które przejęło stery władzy w Polsce po 1989 roku wnosiło doświadczenie i wiedzę zdobytą zazwyczaj w okresie zniewolenia społecznego i ekonomicznego. Wynikiem dominacji państwa i partii komunistycznej było powszechne ubezwłasnowolnienie przejawiające się brakiem aktywności $\mathrm{w}$ wymiarze lokalnym i w rozwiązywaniu często najprostszych spraw mających podstawowe znaczenie (por. Kozłowski, 1991). Powszechne było oczekiwanie na decyzje płynące z centrum zarządzania państwem i, co też było znamienne, centralne organy władzy państwowej niechętne były do decentralizacji swoich uprawnień do samorządów gminnych i organizacji pożytku publicznego (por. Kozłowski, Ciborowska-Kubiak, Nawrolska, 1996). Uchwalenie ustawy o samorządzie terytorialnym ${ }^{1}$ dało początek przemianom zmierzającym do przesunięcia uprawnień sektora publicznego z centrum do samorządów terytorialnych. Chociaż z dużym oporem postępowało i nadal postępuje przesuwanie kompetencji do samorządów terytorialnych i organizacji pożytku publicznego oraz wdrażanie nowoczesnych metod zarządzania w sektorze publicznym, to jednak szczególnie gminy otrzymują coraz to nowe uprawnienia. Można też zaobserwować stale rosnący, wśród pracowników samorządowych, wzrost kwalifikacji niezbędnych w rozwiązywaniu spraw wnoszonych przez obywateli i ich dotyczących. Rodzi się jednak pytanie, czy kwalifikacje te są wystarczające i czy nadążają za szybko zmieniającymi się warunkami, w których funkcjonują organizacje wykonujące zadania samorządów gminnych. Trzeba bowiem podkreślić, że duży wpływ na efektywne wykorzystanie zasobów organizacji publicznych mają kwalifikacje zatrudnionych w nich osób. Podnoszenie kwalifikacji wiąże się nie tylko $\mathrm{z}$ udziałem $\mathrm{w}$ formach kształcenia, ale też z zasobami finansowymi niezbędnymi do pokrycia kosztów tych szkoleń i stworzeniem programu

1 Ustawa z dnia 8 marca 1990 roku o samorządzie terytorialnym (Dz.U. z 1990 r. poz. 95). Z dniem 29 grudnia 1998 roku tytuł ustawy otrzymał brzmienie - Ustawa z dnia 8 marca 1990 roku o samorządzie gminnym (na podst. Dz.U. z 1998 r. Nr 162 poz. 1126). Następnie ustawa została zmieniona ustawą z dnia 8 lipca 2005 roku o zmianie ustawy o samorządzie gminnym oraz niektórych innych ustaw (Dz.U. z 2005 r. Nr 175, poz. 1457) z dniem rozpoczęcia kadencji wójtów (burmistrzów, prezydentów miast) następującej po kadencji, w czasie której ustawa zmieniająca została ogłoszona. 
motywującego do podnoszenia kwalifikacji, w którym istotne jest indywidualne zaspokojenie potrzeby dysponowania wiedzą niezbędną do rozwiązywania problemów i też tworzącą szansę awansu zawodowego. Aby osiągnąć sukces w realizacji programu podnoszenia kwalifikacji, należy stworzyć system motywujący do udziału w szkoleniach uwzględniający indywidualne potrzeby i opierający się nie tylko na dostarczaniu wiedzy czy kształtowaniu umiejętności, ale też wpływający na postawę. $\mathrm{W}$ budowie systemu motywującego do podnoszenia kwalifikacji, należy oprzeć się na potrzebach i możliwościach ich zaspokojenia. Podnoszenie kwalifikacji zawsze wiązać się powinno z systemem nagród, ale też kar w przypadku odmowy udziału $\mathrm{w}$ przyjętym programie podnoszenia kwalifikacji. Program powinien być stale doskonalony i weryfikowany, aby jego końcowe efekty najlepiej służyły realizacji zadań na stanowisku i przez organizację (Pocztowski, 2008, s. 203).

Doświadczenia wielu krajów, mających dłuższe doświadczenie w kształtowaniu własnej demokracji i samorządności, a także osiągających wyższe wyniki w rozwoju społecznym i ekonomicznym, ukazują, że stosowanie kompleksowych i nowoczesnych programów wspierania pracowników w podnoszeniu ich kwalifikacji wzmacnia potencjał rozwojowy i też personalny (Wilczyńska, 2013, s. 123 i n.). Podnoszenie kwalifikacji odbywa się poprzez uczestnictwo w różnych formach szkoleń oraz przy wykorzystaniu różnych metod kształcenia. Szkolenie w opracowaniu zdefiniowano jako proces, w którym uczestnik/uczeń pozyskuje wiedzę wzmacniając swoje kwalifikacje niezbędne do osiągnięcia osobistego, ale też zawodowego sukcesu. Autorzy bardzo różnie definiują szkolenie zwracając uwagę na pozyskiwanie kwalifikacji i rozwój ich określonych komponentów (Stredwick, 2005, s. 115), jako działania zainicjowane przez organizację, mające pomóc w uczeniu się człowieka/pracownika, dzięki czemu wzmacnia się jego wkład w realizację celów organizacji (Bramley, 2007, s. 13), czy proces zmieniania wiedzy, postawy lub umiejętności poprzez uczenie się (Armstrong, 2001, s. 448). W ustawie z dnia 20 kwietnia 2004 roku o promocji zatrudnienia i instytucjach rynku pracy szkolenie zdefiniowano, jako pozaszkolne zajęcia mające na celu uzyskanie, uzupełnienie lub doskonalenie umiejętności i kwalifikacji zawodowych oraz ogólnych, potrzebnych do wykonywania pracy, w tym umiejętności poszukiwania zatrudnienia (Art. 2 ust. 1 pkt 37 ustawy z dnia 20 kwietnia 2004 roku o promocji zatrudnienia i instytucjach rynku pracy). Z punktu widzenia interesu przedsiębiorstwa, ale też organizacji sektora publicznego, w tym obywateli tworzących samorząd gminny, zadaniem szkoleń jest utrzymanie i zwiększenie wydajności pracownika. Szkolenia w swoich treściach powinny dążyć do wypracowania umiejętności niezbędnych pracownikowi w realizacji bieżących i przyszłych zadań (Stoner, Freeman, Gilbert, 2001, s. 378).

Zmiany w obszarze potrzeb człowieka sprawiają, że wszystkie organizacje świadczące usługi, w tym przedsiębiorstwa realizujące zadania samorządów gminnych, powinny doskonalić swoje technologie w obszarze zarządzania i wykorzystania wszystkich swoich zasobów. Dlatego muszą stać się z zasady organizacjami uczącymi 
się, zatem stale doskonalącymi swoje procedury celem lepszego wykorzystania zasobów pozostawionych im do dyspozycji. Organizację uczącą się charakteryzuje aktywny udział wszystkich pracowników w doskonaleniu procedur i udział ten warunkowany jest propozycjami zmian ze strony wszystkich członków organizacji. Dlatego konstruktywna krytyka, propozycje zmian, stawianie znaków zapytania i podejmowanie prób zmian są niezbędnym warunkiem postępu (Sekuła, 2008, s. 83-85). W odniesieniu do sektora publicznego potrzeba zmian dyktowana jest rosnącymi i zmieniającymi się potrzebami ludzi. Złożoność problemów, które muszą rozwiązywać przedsiębiorstwa samorządowe, oraz często zmieniające się warunki pracy, otoczenie i przede wszystkim prawo sprawiają, że nieustanne podnoszenie kwalifikacji wymaga organizacji i uczestniczenia w szkoleniach, warsztatach tematycznych, seminariach i wszelkiego rodzaju spotkaniach, obejmujących ściśle określony obszar zagadnień. Ważny jest też stały dostęp do Internetu i możliwość poznawania rozwiązań w innych organizacjach, w tym też kontakt z osobami mającymi do czynienia z podobnymi problemami w samorządach gminnych. Właśnie szczególnie w sektorze publicznym powinien rozwijać się benchmarking, bowiem $\mathrm{w}$ odróżnieniu od sektora prywatnego wzorce płynące z zewnątrz mogą być bez przeszkód wdrażane w każdej organizacji sektora publicznego. Także organizacje sektora publicznego powinny wykorzystywać doświadczenia sektora prywatnego. Poszukiwanie i wybór pewnego wzorca, następnie porównanie tych rozwiązań $\mathrm{z}$ występującymi w organizacji oraz przyjęcie korzystniejszych rozwiązań - zatem benchmarking $\mathrm{w}$ administracji powinien stać się powszechnym procesem wzrostu sprawności zarządzania (Sasak, 2013, s. 194).

Obok udziału w szkoleniach zewnętrznych, każdy pracownik wykonujący zadania merytoryczne, stąd mający wpływ na sprawy obywateli, powinien doskonalić swoje umiejętności na stanowisku pracy. Jest to o tyle istotne, że nie ma przerwy w wykonywaniu obowiązków służbowych, co w organizacjach małych, zatrudniających niewielką liczbę pracowników - a tak jest często w organizacjach wykonujących zadania samorządów gminnych, ma bardzo duże znaczenie. W nauce wyróżnia się cztery główne metody systematycznego doskonalenia swoich umiejętności na stanowisku (Stoner J.A.F., Freeman R.E., Gilbert D.R. 2001, s. 380 i n.), które można zastosować również w organizacjach wykonujących zadania samorządu gminnego:

- wychowywanie (trenowanie), zatem prowadzenie procesu uczenia przez bezpośredniego przełożonego, który z zasady powinien być lepiej przygotowany do realizacji zadań i mieć większe doświadczenie w pracy;

- z uwagi na niewielką liczbę pracowników przedsiębiorstw komunalnych, konieczne jest częste zastępowanie współpracowników i dlatego sprawdza się w systemie szkoleń rotacja, dzięki której pracownicy poznają szerszy obszar funkcjonowania organizacji;

- kierowanie pracowników na staże szkoleniowe polegające na przyporządkowaniu pracownika doświadczonemu i o wysokich kwalifikacjach 
pracownikowi, co daje możliwość czerpania wzorów dobrej i efektywnej pracy mających zastosowanie w przyszłości;

- przydzielanie szkolonym ważnych zadań, wcześniej precyzyjnie opisanych i zaplanowanych, tak aby w toku ich realizacji pracownik poznawał całokształt spraw, którymi organizacja się zajmuje i wyrobił w sobie umiejętności współpracy z otoczeniem.

Prowadzone badania wskazują jednak z jednej strony na dużą rotację kierowników organizacji wykonującej zadania samorządu gminnego, co wynika z dużego upolitycznienia $\mathrm{w}$ dziedzinie kadr, bowiem kierownicy organizacji gminnych podlegają bezpośrednio lokalnym politykom, którzy najczęściej dokonują zmian i wyboru kierując się interesem partyjnym, a nie kwalifikacjami. Z drugiej zaś strony często obserwuje się zatrudnianie osób niezagrażających swoimi kwalifikacjami kierownikom przedsiębiorstw komunalnych, stąd osób, których podstawowym zadaniem jest bezdyskusyjna realizacja poleceń przełożonego. Do rzadkości należy transparentne zarządzanie w obszarze polityki kadrowej, wykonywania kompetencji organizacji i wykorzystania zasobów organizacji (Kozłowski A. J., Czaplicka-Kozłowska, 2010, s. 264 i n.).

\section{Wyniki badań własnych}

Sprawne funkcjonowanie sektora publicznego jest funkcją wielu składających się na to czynników, wśród których kwalifikacje zawodowe zatrudnionych w niej pracowników mają znaczenie podstawowe. Wraz z decentralizacją zadań do samorządów na najniższym szczeblu w strukturze zarządzania państwem wzrosło znaczenie kwalifikacji kadr zawiadujących zasobami dobra wspólnego oraz realizujących zadania mające podstawowe znaczenie dla obywateli. To właśnie sprawiło, że w trakcie badań podjęto kwestię kwalifikacji pracowników jednostek organizacyjnych wykonujących zadania samorządów gminnych na Warmii i Mazurach, w tym problem wzrostu lub spadku tych kwalifikacji w ciągu ostatnich lat. Badania ankietowe prowadzili specjalnie przygotowani ankieterzy, którzy w wyznaczonych terminach rozdali ankiety osobom (pracownikom) wchodzącym do wybranych losowo organizacji, z wyjątkiem placówek oświatowych i urzędów oraz zebrali je do specjalnie przygotowanych urn w taki sposób, aby zapewnić pełną anonimowość. Ankieterzy rozdali ankiety bezpośrednio i też osobiście je zbierali, co miało zagwarantować anonimowość badań. Po zebraniu ankiet zostały one wprowadzone do bazy, a wyliczenia dokonano wykorzystując oprogramowanie komputerowe SPSS (Statistical Package for the Social Sciences). Badanym pracownikom przedsiębiorstw komunalnych zadano pytanie, czy w ich zakładzie w ciągu ostatnich 5 lat podniósł się poziom kwalifikacji zawodowych. Pytanie miało charakter zamknięty, bowiem przedstawiono trzy propozycje odpowiedzi bez możliwości dopisania 
własnych. Odpowiedziało na nie 1050 osób (analiza odnosi się do różnej liczby cech, bowiem nie wszystkie osoby wypełniły metryczkę na końcu ankiety), w tym ponad połowa (54\%) potwierdziła, że nastąpił wzrost kwalifikacji, a jedynie $12,5 \%$ zaprzeczyło temu stwierdzając, że kwalifikacje nie poprawiły się i aż co trzeci badany (33,5\%) nie potrafił odpowiedzieć na to pytanie (tab. 1). Z badań wynika, że w jednostkach organizacyjnych wykonujących zadania samorządów gminnych dominują kobiety, bowiem wśród badanych było ich $70 \%$. Jest też zdecydowana przewaga osób z wykształceniem wyższym $(73,6 \%)$ oraz osób pracujących na stanowiskach samodzielnych $(78,4 \%)$, a najmniej na stanowiskach kierowniczych $(7,8 \%)$. O tym, że kwalifikacje w ostatnich 5 latach wzrosły przekonane są przede wszystkim kobiety $(54,4 \%)$, a nie mężczyźni (53\%) oraz osoby z grupy wiekowej 50-59 i 30-39 lat (55,8\%). Natomiast badani w wieku powyżej 60 lat (40,9\%) oraz 18-29 lat (48,3\%) w najmniejszym stopniu przekonane są o podwyższeniu się kwalifikacji osób w ich zakładzie pracy. Właśnie w tych dwóch grupach wiekowych aż 43,5\% (18-29 lat) i 40,9\% (powyżej 60 lat) badanych stwierdziło, że nie wiedzą, czy kwalifikacje podniosły się czy nie, i aż 18,2\% w grupie wiekowej powyżej 60 lat stwierdziło, że kwalifikacje nie podniosły się.

Analizując odpowiedzi według stażu pracy w obecnym zakładzie i w ogóle oraz w sektorze publicznym, wykształcenia i pełnionej funkcji w zakładzie, trzeba zauważyć współzależności między cechami badanych osób i wypowiedzianymi opiniami. Osoby o najwyższym statusie wykształcenia najczęściej wskazały na podwyższenie kwalifikacji pracowników (56,1\%) i odsetek wskazań maleje do 51,4\% wśród osób ze średnim wykształceniem oraz do $42 \%$ z wykształceniem poniżej średniego. Podobnie osoby z najdłuższym stażem w ogóle najczęściej wskazały na podwyższenie poziomu kwalifikacji współpracowników $(62,2 \%)$ i odsetek wskazań spada mniej więcej równomiernie do $45,8 \%$ w grupie o najkrótszym stażu poniżej 1 roku. Podobnie w odniesieniu do stażu pracy w obecnym zakładzie odsetek wskazań spada od 62,3\% wśród osób o stażu powyżej 10 lat do 44,1\% o stażu poniżej 1 roku. Także w odniesieniu do liczby lat pracy w sektorze prywatnym osoby niepracujące $(57,6 \%)$ najczęściej wskazały na podwyższenie kwalifikacji pracowników i następnie osoby o najdłuższym stażu pracy w sektorze prywatnym $(55,7 \%)$ - odsetek wskazań spada do 44,5\% wśród osób, które najkrócej pracowały w sektorze prywatnym. O tym, że kwalifikacje pracowników wzrosły przekonani są przede wszystkim badani wykonujący funkcje kierownicze (57,3\%), następnie pracujący na stanowiskach samodzielnych (56,4\%) i zdecydowanie mniej wykonujący prace proste (38,5\%). Także pracownicy zamężni (56,1\%) częściej niż na wsi wskazali na rosnące kwalifikacje swoich współpracowników (48,2\%). 
Tabela 1. Podwyższanie kwalifikacji zawodowych

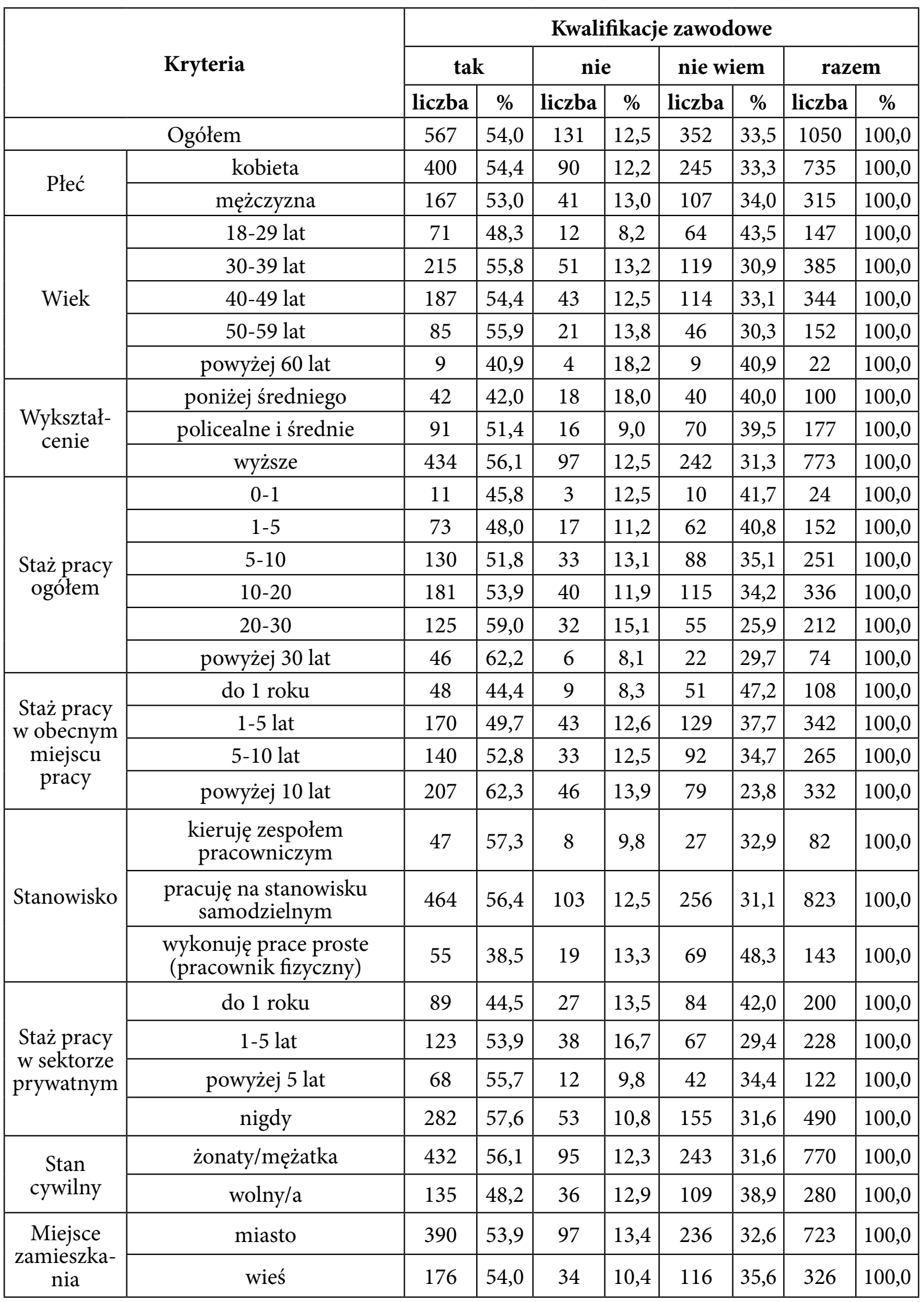

Źródło: opracowanie własne na podstawie badań 


\section{Podsumowanie}

Niewątpliwie kwalifikacje pracowników różnego rodzaju przedsiębiorstw są nie tylko warunkiem ich rozwoju, ale też mają wpływ na osiągnięcie osobistego sukcesu przez pracownika. Badania jednoznacznie dowodzą, że sukces człowieka w zasadzie jest wynikiem wysokich kwalifikacji i w tym umiejętnego wykorzystania wiedzy dla wprowadzania modyfikacji w stale zmieniającym się otoczeniu. Dlatego podjęta w opracowaniu problematyka kwalifikacji pracowników organizacji wykonujących zadania samorządów gminnych jest próbą oceny, czy kwalifikacje pracowników rosną i nadążają za zmieniającymi się warunkami otoczenia. Przed podjęciem badań przyjęto, że następuje stały wzrost kwalifikacji pracowników samorządowych. Badania potwierdziły też, że wzrost ten zróżnicowany jest w odniesieniu do różnych grup zatrudnienia. Można przyjąć, że kwalifikacje pracowników przedsiębiorstw komunalnych są coraz wyższe, wskazują na to wyniki badań, nie dają jednak odpowiedzi na pytanie, czy zmieniają się zgodnie z oczekiwaniami i potrzebami organizacji i konsumentów usług realizowanych przez te organizacje. W wyniku badań można sformułować następujące generalne wnioski:

- $\quad$ wśród badanych pracowników zakładów wykonujących zadania samorządów gminnych dominuje przekonanie, że kwalifikacje zatrudnionych tam osób w ciągu ostatnich lat wzrosły;

- jednocześnie co trzeci badany nie miał na ten temat zdania a ponad $12 \%$ było przekonanych, że kwalifikacje nie wzrosły;

- największą wiedzę o tym, czy kwalifikacje wzrosły czy nie, mają osoby legitymujące się wykształceniem wyższym i pracujące na stanowiskach kierowniczych;

- pracownicy wykonujący prace proste i mający wykształcenie na najniższym poziomie najczęściej nie potrafili odpowiedzieć, czy kwalifikacje w ich zakładach pracy wzrosły czy nie.

Badania wykazały też, że w organizacjach wykonujących zadania samorządów gminnych dominują kobiety, tak jest w przedsiębiorstwach komunalnych, placówkach oświatowych i urzędach obsługujących organy gminne. Interesujące jest też to, że najczęściej kierownikami organizacji wykonujących zadania gmin są mężczyźni zatem mężczyźni bardzo często kierują organizacjami zdominowanymi przez kobiety.

\section{BIBLIOGRAFIA}

[1] Amstrong M., 2001, Zarzadzanie zasobami ludzkimi, Oficyna Ekonomiczna, Dom Wydawniczy ABC, Kraków.

[2] Bramley P., 2007, Ocena efektywności szkoleń, ABC a Wolters Kluwer business, Kraków.

[3] KozŁowski A. J., Ciborowska-Kubiak M., Nawrolska I., 1996, Samorząd Terytorialny. Zarządzanie finansami lokalnymi, Wyższa Szkoła Biznesu w Pile. 
[4] KozŁowski A. J., Czaplicka-KozŁowska I. Z., 2010, Samorząd terytorialny w systemie zarzadzania państwem. Wybrane problemy. Pracownia Wydawnicza ElSet, Olsztyn.

[5] KozŁowski A. J., 1991, Kadra kierownicza administracji państwowej, Wydawnictwo Ostrołęckie Towarzystwo Naukowe, Ostrołęka.

[6] Pocztowski A., 2008, Zarządzanie zasobami ludzkimi. Strategie-procesy-metody, PWE, Warszawa.

[7] SASAK J., 2013, Benchmarking procesów jako narzędzie doskonalenia administracji publicznej, [w:] Frąckiewicz-Eronka A. (red.), Zarządzanie publiczne: koncepcje, metody, techniki, Studia Ekonomiczne, Uniwersytet Ekonomiczny w Katowicach, Katowice.

[8] SekuŁa Z., 2008, Motywowanie do pracy. Teorie i instrumenty, PWE, Warszawa.

[9] Stoner J. A. F., Freeman R. E., Gilbert D. R., 2001, Kierowanie, PWE, Warszawa.

[10] Stredwick J., 2005, Zarządzanie pracownikami w matej firmie, Small Business, Warszawa.

[11] Ustawa z dnia 20 kwietnia 2004 roku o promocji zatrudnienia i instytucjach rynku pracy (Dz.U. $2004 \mathrm{nr}$ 99, poz. 1001).

[12] Ustawa $z$ dnia 8 lipca 2005 roku o zmianie ustawy o samorządzie gminnym oraz niektórych innych ustaw (Dz.U. z 2005 r. nr 175, poz. 1457).

[13] Ustawa z dnia 8 marca 1990 roku o samorządzie gminnym (Dz.U. z 1998 r. nr 162, poz. 1126).

[14] Ustawa z dnia 8 marca 1990 roku o samorządzie terytorialnym (Dz.U. z 1990 r., poz. 95).

[15] Wilczý́ska A., 2013, Podnoszenie kompetencji pracowników struktur samorządowych, [w:] Wolniak R. (red.), Współczesne metody i techniki zarządzania - podejście interdyscyplinarne, Organizacja i zarządzanie, Zeszyt sześćdziesiąty siódmy, Wydawnictwo Politechniki Śląskiej, Gliwice. 